\title{
THE IMPLEMENTATION OF JIGSAW IN TEACHING ESP SPEAKING FOR ACCOUNTING DEPARTMENT IN UNIVERSITY OF MUHAMMADIYAH LAMONGAN
}

\author{
Naajihah Mafruudloh \\ Universitas Muhammadiyah Lamongan
}

ichastudy07@gmail.com

\begin{tabular}{llc}
\hline Received: 23 May 2020 & Accepted: 24 June 2020 & Published : 31 July 2020 \\
\hline
\end{tabular}

\begin{abstract}
Speaking is a part of spoken and productive skills. In oral communication, the speakers and listeners are actively involved in the message. The speakers transfer a message in the appropriate language, and listeners have to interpret the message. Brown (2004) defines speaking as a productive skill that can be directly and empirically. In teaching speaking, lecturers should have a proper technique to enhance the students to be more active in the speaking class. Therefore, teachers need some appropriate techniques face that condition. Jigsaw is one of cooperative learning method that will help the students gain the information not only by reading the materials, but also sharing and discussing with their friends. Jigsaw consists of several groups, in which every group consists of several students who have various in ability, gender, religion and race. The purpose of this study was to describe the implementation of Jigsaw, the supporting factors in Jigsaw, and the teacher's obstacles in implementing Jigsaw. In conducting this study, the writer applied descriptive qualitative research as the research design because it described the phenomena that exist in the Jigsaw implementation. The data are collected in the form of words. The reseacher used observation and interview to gain the data. Based on the result that concluded, there were 3 important points. First, choosing material, making lesson plan, organizing Jigsaw in classroom, giving quiz, and evaluating were the steps in implementing Jigsaw for speaking class. Then supporting factors were media, professional teacher, situation surround the class, material, student's motivation, and class management. Third, limited time and different level of student's comprehension were the obstacles that faced by the lecturer. In conclusion, Jigsaw was recommended for teaching Speaking, because it gained the students to be more active and interactive in teaching and learning process.
\end{abstract}

Keywords: Jigsaw, English for Specific Purposes, Speaking skill

\section{To cite this article:}

Mafruudloh, N. (2020). The Implementation of Jigsaw in Teaching ESP Speaking for Accounting Department in University Muhammadiyah of Lamongan. Journal of Research on Language Education, 1(1), 6-12.

\section{INTRODUCTION}

It is well-known that lecturer as the important or knowledge sources in the class. It seems that the lecturers only give some explanations about the material, and the students listen to them. In fact, a lecturer is not always as a knowledge and information sources. Student's participation is needed in teaching and learning process, from this way the students will obtain knowledge from their lecturer, they will also develop their ability especially in speaking skill.

In Indonesia, English is taught as a compulsory subject. In non-English department, it is called as an English Specific Purposes (ESP). The lecturer should deliver a proper material related to the students' field of study while teaching ESP (Wahyudin, 2017). In a straightforward and pragmatic way, ESP is as the teaching and learning of English as a second or foreign language where the goal of the learners is to use English in a particular subject (Isani, Paltridge, \& Starfield, 2013). It is a way of teaching and learning English for specialized subjects with some specific vocational and educational purposes in mind. Furthermore, Basturkmen (2010) adds that ESP courses are narrower in focus than general English language teaching (ELT) courses because the center is on the analysis of learners' needs. It concludes that, ESP can be defined as the branch of English learning where the material and the activity focuse on the learners' specific needs. 
In teaching speaking for ESP, the lecturers teach speaking based on the students' abilities in their subject-matter fields in order to improve their ability to acquire English (Wahyudin, 2017). Subject-matter knowledge gives them the context they need to understand the English classroom. Brown (2004) defines speaking as a productive skill that can be directly and empirically observed; those observations are consistently colored by the accuracy and effectiveness of a test-taker's listening skill, which necessarily compromises the reliability and validity of an oral production test.

In speaking class for ESP, students are shown how the subject-matter content is expressed in English. The lecturer can make the most of the students' knowledge for the subject matter, thus helping them learn English faster. Fiorito (2005) stated that ESP combines subject matter and English language teaching. Such a combination is highly motivating students because they are able to apply what they learn in their English classes to their main field of study, whether it be accounting, business management, economics, computer science or tourism. Being able to use the vocabulary and structures that they learn in a meaningful context reinforces what is taught and increases their motivation.

To motivate the students for their participation in speaking class, the lecturer should have a good method, teaching technique or teaching media to encourage students in learning. As Oktaviani and Desiarti (2017) said that both lecturer and students agreed that teaching speaking needs to use a unique and attractive way to improve the quality of learning. Moreover, Gillies and Ashman (2003) stated that Cooperative Learning is kind of group activity, it consists of some group members that have actively coordinate their efforts. It ensures that all of members in the group have the same opportunities to contribute, help, and support to encourage their friends or partner. The students who are joining as group members would be friendlier, cohesive, and motivated than their peers in competitive situation. Groups would be more productive as members demonstrate a willingness to listen to each other and work together to produce a group product that is qualitatively better than those who work competitively. The learning activity was well organized so that learning is dependent on the socially structured exchange of information between learners in groups and in which each learner is held accountable for his or her own learning and is motivated to increase the learning of others (Lestari and Wahyudin, 2020).

Jigsaw is one of cooperative learning method. It consists of several groups, in which every group consists of several students who have heterogeneous in ability, gender, religion and race. Every member in Jigsaw group has same important role, because their contribution will complete the task. Every student in Jigsaw group also has same responsibility. The students also have to share their knowledge and information to other members in their group, to solve the problems that appear in the materials.

Based on the preliminirary study that held by the researchers on 25 February 2020, it found that most of the students could not involve in the speaking actively, some of students said that they feel afraid in constructing the grammar structure. Some of them also stated that, they have no ideas and vocabulary to share. To solve the problem in Speaking, the situation in the class must be changed from a competitive atmosphere class into more cooperative one. It also will make the student's motivation and participation increase. Therefore, it is an important thing that lecturer will help the students more cooperative and active. The implementation of teaching speaking using Jigsaw also implemented by Utari (2013) and Dyna (2013), they stated that Jigsaw could be one of solution for encouraging the students to be more active in the class. In other hand, Rika (2017) found that when implementing the Jigsaw, some of the students still have difficulties in sharing ideas; because they have no proper and enough time. Then lackness of vocabulary also could be the problem found in her research.

Knowing the importance of Jigsaw technique, the researcher is going to know the implementation of teaching speaking for ESP students by using Jigsaw in Accounting Departement at Universitas Muhammadiyah Lamongan. Since Jigsaw is also one of cooperative learning method, it will help the students easier to gain vocabulary, share ideas, and discuss with their partner. Jigsaw also can change the class situation, from competitive class into more cooperative one. Considering the statement above, the researcher is intended to conduct a research with the research questions: (1.) How does the lecturer implements the Jigsaw for ESP speaking class? (2.) What are the obstacles faced by the lecturer in implementing Jigsaw on her/his ESP Speaking class? 3. What are the important factors that used in Jigsaw for teaching ESP speaking?

\section{RESEARCH METHOD}

There are several methods which are used for processing the data or solve some problems in this research. Therefore, this research used certain methods to make the data more systematic and get an accurate result of the discussion. According to Lodico, Spaulding, and Voegtle (2006) research method is the specifically on the proposed study and it describe the researcher's plans to carry out the study. The researcher used a qualitative descriptive research design. According to Ary (2010), qualitative research is employs words and images to answer the questions. It also investigates the 
quality of relationships, activities, situation, and materials. It focuses on understanding the context and attempts to explain the intentionality of behaviors. Based on the explanation above, this research uses descriptive qualitative research design in nature, because its objective means to answer some questions naturally concerning with the current status of the subject of this study and the writer also described the implementation of Jigsaw teaching technique specifically in the real condition.

There was a lecturer who teaches English for Specific Purposes (ESP) speaking in Accounting Department at Muhammadiyah University of Lamongan as the research subject. The research held in four meetings to gain the data by using observation, and one meeting to have an interview with the lecturer. In this part, the researcher used observation for answering the first and third research question and interview for adding some important data that the researcher needed.

\section{FINDINGS AND DISCUSSION}

This part was to answer three research questions: (1.) How does the English lecturer implement the Jigsaw teaching technique for Speaking skill? (2.) What are the obstacles faced by the lecturer in implementing Jigsaw for Speaking skill? (3.) What are the important factors that support the Jigsaw teaching technique in Speaking skill?

\section{THE IMPLEMENTATION OF JIGSAW FOR SPEAKING SKILL}

In Jigsaw implementation, the researcher observed six aspects of the Jigsaw for Speaking skill, there were: the lecturer's reason, the steps of Jigsaw, the material for Jigsaw, the lecturer's role in implementing Jigsaw, the student's role in Jigsaw activities, the advantages, and weakness of Jigsaw.

1. The lecturer's reason

There are several reasons, why the lecturer implemented Jigsaw in her Speaking class. It shown by interview with the lecturer that Jigsaw is one of Cooperative Learning. Jigsaw was different with the other technique. In Jigsaw the lecturer encouraged the students to comprehend the whole of materials. From expert group the students understood and discussed about their material in their own group. After that, they regrouped into Jigsaw group. Jigsaw group gave the students main responsibility as a tutor to their friends in their own Jigsaw group. They would share the material that they had in expert group. They also had to ask and shared each other. They had to know their friend's material. Then the students came back to the first group, expert group. In the last group, they had to discuss and share the whole of materials that they had. Each person in the group had to spoke up and shared what they had. Jigsaw was one of interesting technique. The students shared and moved from one student to another group. It also made the students try to be responsible with their task. Even though, the students worked with their group, they had to understand the material, because for evaluating the activity, the lecturer would ask question to the students randomly and they have to answer it. Third, Jigsaw also motivated the students to be more active in the class. They had to be active by saying or telling the material. Jigsaw should apply in seldom time, because if it applied often the student would get bored easily.

\section{The steps of Jigsaw}

According to the class observation (See appendix 1), there were 5 steps in implementing Jigsaw for Speaking class by the English lecturer:

- Choosing the material and Topic

Before implementing Jigsaw, the lecturer choosed some appropriate materials according to the semester, field of study, etc. The lecturer also made different material and quizzes, because Jigsaw needs various materials for different groups.

- Making Lesson Plan

Lesson plan was common important for learning activities in the classroom. It was as the handle of the lecturer when he/she was teaching. In implementing Jigsaw, the lecturer made the lesson plan for planning the schedule, dividing the time, making group, giving quizzes, etc.

- Organizing Jigsaw in the classroom.

Jigsaw classroom was one of type of Cooperative Learning method. The students not only done the task by themselves, but also they had to do the task together with their group. One students and other student in every group were a partner. They had to trust and help each other. There were some stages for organizing Jigsaw in the classroom, they are:

a. Dividing the students in some groups (Expert group)

The lecturer divided the students in 6 groups and each group contained of 5 students. In the expert group the lecturer gave different material or topic for every group. The lecturer also gave the 
students time to make discussion with their group. The lecturer also made sure to the student that the students had to understand about their topic. While the students had discussion with their group, the lecturer goes around in every group. The lecturer also invited the students to discuss actively. Every student had a change for asking, answering, and giving opinion according to the topic that they had.

b. Regrouping the students in Jigsaw group.

After they discussed in expert group, the lecturer regrouped the students in Jigsaw group. Jigsaw consisted of several students that had different topic. Each student in Jigsaw group had already understood about their topic in Expert group. So, in Jigsaw group the students shared each other what the topic that they have got in expert group. In this group the lecturers also gone around the class, while the students discussed with their group. So, in Jigsaw group all of the students in the classroom had to understand the whole of the topic. In this part the students asked to be more actively, even some of the students faced difficulties in contructing words, sharing ideas, because the lack of their vocabulary. The lecturer's role is important. She facilitiated and guided them to produce more vocabulary, even they still mixed their English and Bahasa.

c. Grouping in the home group (Expert group)

The lecturer asked students to come back to their first group or home group. In the home group the lecturer asked the students to make a short discussion about the whole of the topics that they got from the other group.

- Giving quiz to the group and writing summary.

In this step, the lecturer gave the students some spoken questions and asked the students to present orally in front of the class. The questions were related to the whole of topic. But, in this step the lecturer gave question and also pointed the student randomly.

- Evaluating

The lecturer evaluated after the learning process done. The lecturer also explained the material and the topic and gave the students some simple questions. The lecturer also motivated student in doing Jigsaw. To minimize the students' anxiety, sometimes the lecturer said in Bahasa and gave some jokes.

\section{Material in Jigsaw}

The material used by the lecturer was related the students' field of study, such as promoting products and giving instructions. The materials for Speaking were taken from text book and the other sources such as internet related to the material. The questions for each material are made by the lecturer and some of them were taken from the text or other sources. The lecturer used advertisement and procedural for the material. She also gave the group same material but in different topic or title.

\section{The lecturer's role in Jigsaw for Speaking class.}

- Lecturer as facilitator

In implementing Jigsaw, the lecturer became a facilitator, because the lecturer prepared the materials and the topic. Besides, the lecturer also guided the discussion process. For example, the lecturer guided the students to discuss and share with their group by asking them, "What does the topic tell about?". The lecturer not only becomes a facilitator in one group, but also to another groups. After the students done with their discussion in first group or expert group, the lecturer asked them to make new group "Jigsaw group". The lecturer also remained that in discussing the materials, one student to other students were important, because if one student did not understand the material, the other students would not understand too. She remained the students by saying, "Make sure that every student in your group understand the whole of materials!"

- Lecturer as motivator

The class consists of 25-30 students that had different knowledge and background. The students also had different motivation in learning English. Some of them were active. They discussed and spoke up actively in their group. But, some of them were also passive. They only depend on their friend who had upper level of comprehension. So they did not understand the material. In this case, the lecturer motivated the entire students to speak up. Motivational words were also important for the students who were not active. It would make them more spirit to do their task. In the end of the class, the lecturer gave them motivation to study hard. Besides, the lecturer also motivated the students to discussed, asked, and answered in Jigsaw process.

- Lecturer as source of knowledge and information

In learning process, sometimes the lecturer was a main source of knowledge and information for the students. The lecturer explained and shared the whole information and knowledge related to the topic and material. Before applied Jigsaw, the lecturer gave the students directions and role in Jigsaw. The 
lecturer also made correction in student's error. Then after Jigsaw end, the lecturer explained and shared the information related to the material.

- Lecturer as Evaluator

In the end of Jigsaw implementation, the lecturer gave some tasks or questions related to the material. It was for evaluating and reflecting the teaching and learning process. The lecturer also gave the students clarification and feedback in every part (Wahyudin, 2018).

5. The students' role in Jigsaw implementation.

- Student as a tutor or as deliverer of information

In Jigsaw, the students should know and understand the whole of information in those different topics. To get the information, they shared each others. It can be shown by the interview with the lecturer and also the observation that students had to deliver and share the whole of information spoken. The students also explained the information related to the materials until their friends understand.

- Student as a helper to their friend

Cooperative way was really needed in Jigsaw. First, Jigsaw has several groups that consist of various levels of students. In every group also consist of some students who have different background of knowledge and level of comprehension. It can be shown by interview with the lecturer. She said that students who had upper level of ability would help their friends who had lower level of comprehension. By this way, the students in each group got new knowledge and shared each other. The lecturer also said that by Jigsaw the students would not shy or afraid to ask their friends in sharing the materials orally.

6. The advantages and the weakness of Jigsaw.

Based on the observation and interview as an additional instrument, the researchers concluded that there were some advantages and weaknesses in implementing Jigsaw for speaking skill. First, Jigsaw was an alternative to encourgage the students for having interactive interaction and communication among the students in the class. It helped the students to be more active and added some new vocabularies. It meant that Jigsaw could be a way to develop the student's social language.

Then, there were also some weaknesses in Jigsaw. It could not apply in difficult material and the students who had low in English skill also had low attention on it. In Jigsaw, the students had to have a knowledge and basic information. When it applied in the students who had low attention, they could not follow the procedures and instructions effectively. It also could be make the class bored and need more time, if it applied in difficult materials.

\section{THE OBSTACLES IN JIGSAW IMPLEMENTATION}

Base on the interview, there were two obstacles that faced by the lecturer. First, limited time was one of the obstacles that faced by the lecturer. Because, in implementing Jigsaw she needed more time to introduce the material and the rule of Jigsaw. The Jigsaw implementation also need more time, because the students need to discuss one group to another group. The second obstacle is different Level of Student's ability. In Jigsaw groups consist of several students that had different level of ability. Sometimes some students did not respect the material, certainly the other students would get the impact. Their friends would not know about the material, because one of the students in that group did not respect and responsible in her/his task

\section{THE TEACHING AIDS THAT SUPPORT JIGSAW IMPLEMENTATION}

Jigsaw was cooperative learning technique. In implementing Jigsaw, there were some aids that support Jigsaw implementation. There are six factors that support Jigsaw implementation in speaking class. The first was structure. In this part structure meant material, media, and professional teacher. Materials in Jigsaw have the same length, difficulties, and level. The material could be influenced the student's comprehension. One group and other group got different material but in same level. It would help them to comprehend the materials easily. Media was also important for Jigsaw implementation. Without appropriate media, the class would be boring. The lecturer used short functional text (advertisement) and real media such as product to promote, etc. Because of some attractive media, the students were more motivated (Sari and Wahyudin, 2019a; Sari and Wahyudin, 2019b).

The second part is coming from students' management. In management includes class management and the situation surround the class. In Jigsaw for accounting class, Dividing the students in some groups is one way to manage the class. The lecturer divided the student randomly by asked them to count $1-4$, then the students 
met the same number, because in the class consists of different level of comprehension's students. After that the teacher regrouped the students in Jigsaw group. The students were one factor of the class management. So, in this factor the teacher had to have some good ways to manage the students. Then the situation surround the class also influenced to support the Jigsaw implementation. The student's motivation sometimes came from the class situation. The students would have high motivation when Jigsaw implemented in the beginning of the class (in the morning). But, some students had low motivation when Jigsaw implemented in the end of the class. Hence, it depends of the time when the jigsaw is implemented.

The last was social skill. In social skill came from the team member or the students itself. Social skill includes students motivation and different level of students ability in speaking. Student's motivation also could be one of the supporting factors in implementing Jigsaw, because the students were the center and the main role in Jigsaw implementation. In this case, the students had different motivation. However, the good motivation that the students had, the better implementation would be got.

Aronson stated Jigsaw is a cooperative learning technique that reducing racial conflict and increasing positive educational outcomes (2000). In this teaching technique, the students in a small of "mastery group" or "expert group" had a material that given by their teacher or "expertise area". The materials were different with the other expert groups. The student must comprehend the material by reading it and discussing it with their group members. After sharing the material in their "expertise area", the "expert" from different group met to discuss their topic in mix group or it called as Jigsaw group, and they returned to their groups, and took turns to teach their topics to their group mates. According to Kagan (2009) about variations or types of Jigsaw, they are Jigsaw I the original, assign different material to the students, Jigsaw II assign different tasks based on the same material, and Jigsaw III emphasizes social skill activities and use bilingual learning. In this research the lecturer used Jigsaw I as the technique for speaking skill, because the lecturer used same topics but different material. The lecturer used different text, title, and task but the same topics for the students.

The students who had different level of comprehension would be one of the lecturer obstacles. The participation of one group with another group was different. Every group consists of various levels of comprehension students. Some of them were active and answered the questions correctly, but some of them were not. Sometimes, it would give the other students unsatisfactory impact. But, here the teacher solved it by guiding them in one group to another groups. So, the students asked the lecturer about the problem faced in learning process. Besides the students who had different level of comprehension, Jigsaw needed more time, especially for difficult or unfamiliar material. The teacher solved it by selecting material that has easy topic to discuss. So, the teacher only shared and explained the rule of Jigsaw implementation. Murniati (2014) also found that in implementing Jigsaw the teacher got difficulties in preparing the material. In this part, the teachers/lecturers shoul make a proper material. It realated to the students' ability and field of study.

In Jigsaw implementation, there were some aspects that support it. One aspect to another aspect were related each other. The teacher in Jigsaw was not as the centre or the main role. The teacher only shared and explained the rule, motivated the students, facilitated the students, and also evaluated the students. In Jigsaw, the main role was the students. They moved one group to other group for discussing and sharing with their group, also solving the problems together with their group. In Jigsaw the student's motivation and student's level comprehension were also important. It was related to Putri (2014) said that Jigsaw trained the students' ability to think in particular reasoning. Therefore, if at the end of the lesson the students are given the conceptual understanding tests, they will have no difficulties in answering such questions. All of these are because they are already trained about their reasoning abilities when learning to use this Jigsaw cooperative learning model. In the end, the implementation of the Jigsaw cooperative learning model could improve the students' learning activities and improve the students' learning outcomes in the cognitive domain which can be said to be successful.

\section{CONCLUSION}

Based on the Jigsaw implementation in English for Specific Purposes (ESP) for Speaking class, there were some important conclusions that can be concluded by the researcher. First, the lecturer implemented Jigsaw using some steps. There were choosing material and topic, making lesson plan, organizing Jigsaw in classroom, giving quiz, and evaluating. The teacher also encouraged the students to comprehend the whole of material. From expert group, the students understood and discussed about their material in their own group. After that, they regrouped into Jigsaw group. Jigsaw group gave the students main responsibility as a tutor to their friends in their own Jigsaw group. They would share the material that they had in expert group. They also had to ask and share each other. They had to know their friend's material. Then the students came back to the first group, expert group. In the last group, the also had to discussed the whole of material that they had. Each person in the group had to spoke up and shared what they had.

Then there were also seven supporting factors in jigsaw implementation. There were media, professional teacher, situation surround the class, material, student's level of comprehension, student's motivation, and class management. Material in Jigsaw has the same length, difficulties, and level. The material 
could be influenced the student's comprehension. One group and other groups got different material but in the same level. It would help them to comprehend the material easily. The teacher gave same material to the students. It has same length and theme, but different title.

The last lecturer's obstacles, there were limited time and the different level of student's comprehension. In this case, the lecturer solved those obstacles by giving the student short material. The lecturer also made the material in same length, difficulties, and theme. She also solved the different level of student's comprehension by applying the Jigsaw in the end of semester. If the teacher applied Jigsaw in the beginning of the semester, she would make the material more easily and simple.

\section{REFERENCES}

Aronson, E. (2000). Social Psychology Network. Retrieved April 15, 2020, from www.jigsaw.org: http//www.jigsaw.org/overview html

Ary, D. (2010). Introduction to Research in Education. USA: Wadsworth.

Basturkmen, H. (2010). Developing Courses in English for Specific Courses. New Zealand: Palgrave Macmillan.

Brown, H. D. (2004). Language assessment: Principles and classroom practice. White Plains, NY: Pearson Education.

Dyna WS, E. (2013). eprints.uny.ac.id. Retrieved May 10, 2020, from uny.ac.id: http://eprints.uny.ac.id/20523/1/Evi\%20Dyna\%20WS\%2006202241019.pdf

Fiorito, L. (2005). How is English for Specific Purposes (ESP) different from English as a Second Language (ESL), also known as general English? Retrieved November 18, 2019, from www.usingenglish.com: https://www.usingenglish.com/articles/teaching-english-for-specif

Gillies, R. M. (2003). Cooperative Learning. London: Routledge Falmer.

Isani, S., Paltridge, B., \& \& Starfield, S. (. (2013). The Handbook of English for Specific Purposes. Boston: Isey Blackwell. Kagan, S. (2009). Kagan Cooperative Learning. Calle Amanecer: Kagan Publishing.

Lestari, M. and Wahyudin, A. Y. (2020). Language Learning Strategies of Undergraduate EFL Students. Journal of English Language Teaching and Learning 1(1), 25-30. Retrieved at jim.teknokrat.ac.id/index.php/english-languageteaching/article/view/242

Lodico, M. G. (2006). Metodhs in Educational Research. San Fransisco: Jossey-Bass.

Murniati. (2015). The Implementation and Obstacles in Jigsaw Technique in Teaching Reading. jurnal.unsyiah.ac.id, 6.

Oktaviani, L. \& Desiarti, E. (2017). A Lecturer's and Students' Perspective toward Ethnic Snake Game in Speaking Class at Universitas Muhammadiyah Malang. TEKNOSASTIK: Journal Bahasa dan Sastra. 15(2), 53-59. DOI: https://doi.org/10.33365/ts.v15i2.98

Putri, A. J. (2014). The Implementation of cooperative Learning Model Type Jigsaw to Improve students' accouting learning activity and outcomes of grade X AK 3 SMKN 1 Karanganyar. Retrieved March 30, 2020, from eprints.uny: http://eprints.uny.ac.id/14975/1/AGUSTYA\%20JULITA\%20PUTRI\%2010418244017.pdf

Sari, F. M. and Wahyudin. A. Y. (2019). Undergraduate Students' Perceptions Toward Blended Learning through Instagram in English for Business Class. International Journal of Language Education 3(1), 64-73. Retrieved at https://eric.ed.gov/?id=EJ1244402

Sari, F. M. and Wahyudin. A. Y. (2019). Blended-Learning: The Responses from Non-English Students in the Indonesian Tertiary Context. Teknosastik: Jurnal Bahasa dan Sastra 17(1), 23-28. Retrieved at https://doi.org/10.33365/ts.v17i1.204

Utari, R. (2013). Using Jigsaw Technique to Improve the Speaking Ability of the eighth Grade SMPN 3 Depok. Retrieved on May 10, 2020, from UNY: http://eprints.uny.ac.id/21023/1/Risadiah\%20Utari\%2006202244121.pdf

Wahyudin, A. Y. (2017). The Effect of Project-Based Learning on L2 Spoken Performance of Undergraduate Students in English for Business Class. Paper presented on The Ninth International Conference on Applied Linguistics (Conaplin 9), 42-46. Retrieved at https://www.atlantis-press.com/proceedings/conaplin-16/25874124 https://dx.doi.org/10.2991/conaplin-16.2017.9

Wahyudin, A. Y (2018). The Impact of Online Peer Feedback on EFL Students Writing at Tertiary Level. BAHTERA : Jurnal Pendidikan Bahasa Dan Sastra, 17(1), 1-10. https://doi.org/10.21009/BAHTERA.171.1

\section{BIOGRAPHY OF AUTHOR}

Naajihah Mafruudloh was born in Lamongan, on 7th May 1992. She obtained her bachelor and magister degrees in Universitas Muhammadiyah Malang (UMM). She is currently an English specific purposes lecturer in Universitas Muhammadiyah Lamongan. 
